\title{
Utilising Modern Technologies and some Indicators of Mental Health in Pre-school Children in Croatia
}

\author{
Ella Selak Bagarić ${ }^{1}$, Gordana Buljan Flander $^{1}$, Mia Roje ${ }^{1}$, Ana Raguž ${ }^{1}$ \\ ${ }^{1}$ Child and Youth Protection Center of Zagreb, Zagreb, Croatia
}

\begin{abstract}
Although a number of studies have been conducted over the past decade on the association between screen time and developmental outcomes in children, most studies mainly deal with the problem of obesity and physical fitness of children, while the studies on the association of screen time and mental health are rare, and there is especially a lack of research concerning internalized problems in children. Early detection of psychological problems is one of the foundations of later successful prevention and treatment, and some research shows that as many as $20 \%$ of children, including kindergarten children, exhibit certain psychological difficulties, and also that certain behaviours of preschool children are associated with various mental disorders and problems in adulthood. The aim of this research was to examine the correlation between total screen time and some indicators of the mental health of children-emotional reactivity, anxiety / depression, somatic problems, withdrawal, sleeping problems, attention problems, and other problems, in a sample of Croatian children attending kindergartens. We also examined moderating effects of child's involvement in other activities, such as physical activity, playing with peers, overall outdoor activities, and time spent in other activities. In this paper, potential risk and protective factors related to screen time were investigated in preschool children, with a focus on their mental health.
\end{abstract}

Key words: preschool children, screens, leisure time, mental health

Copyright @ 2021 KBCSM, Zagreb

e-mail: alcoholism.kbcsm@gmail.com•www.http://apr.kbcsm.hr

\section{Introduction}

Most modern families have smart mobile phones and tablets, together with TV sets and computers. These devices are easily used when children are nearby and are usually available to parents all the time. Parents

\section{Correspodence to:}

Ella Selak Bagarić, graduate psychologist

Đorđićeva 26, 10000 Zagreb, Croatia

E-mail:ella.selak@poliklinika-djeca.hr also use them to show their children cartoons or other video materials on the Internet [1]. Recent literature has been using the generally accepted phrase 'screen time' meaning the time spent in front of any sort of screen, including smart phones, tablets, TV sets, video games, computers and any other mobile devices [2]. The prevalence of high screen time and its harmful effects on children's health is a serious public health problem [3], and the digital environment is developing faster than 
possible research conducted into the impact on the development, learning and family life of young children [2].

Estimates in literature show that socioemotional and behaviour problems affect 5 - $20 \%$ of pre-school (younger than 5 years of age) children, regardless of population, context and study methodology [4-8]. It is known that certain behaviours of pre-school children are related to various psychological disorders and problems in adulthood $[9,10]$.

Longitudinal study by Caspi and associates [10] finds that children estimated as impulsive, irritable and emotionally unstable at the age of three, showed elevated scores of negative emotionality, and showed antisocial behaviours more frequently at the age of 26; those who were withdrawn and fearful grew up into over-controlling and non-assertive young adults. The results of this and similar studies have significant practical implications because they show that early childhood behaviours have considerable and intense impact on their later life, including the development of social skills, academic achievements and mental and physical health $[11,12]$.

The impact of screen time on the negative developmental outcomes has not been sufficiently studied yet. Studies about the relationship between mental health and screen time in children, especially pre-school children, are scarce.

Research into screen time in young children usually focuses on studying their physical health, i.e. correlation between the amount of screen time and obesity and physical fitness [13-18]. Some studies have found negative effects of watching TV on pre-school population.

Spanish study on 1,000 children aged from 2 to 6 found that $>1.5$ hours of watching TV per day was associated with shorter sleeping time [19]. A lack of research related to internalized problems in pre-school children is especially striking, while externalized issues, the correlation between screen time (especially playing games) and aggressive behaviour as well as attention and concentration difficulties [20-23] have been studied more often. Some studies find that child does not even need to actively use screen time to suffer from the described negative effects; mere exposure to TV set being on even if the child aged 6 to 18 months is doing something else is linked to more externalized issues in children [24].

Groups of renowned international experts drafted recommendations about limiting the total screen time in childhood. For example, according to the Guidelines of the American Academy of Paediatrics, children younger than two should not be exposed to screens at all, while pre-school children could spend max one hour per day with their parents included in the activity [25]. Today, studies show that the average screen time of children exceeds by far the recommended time $[1,26]$ and as many as $90 \%$ of parents ignore these guidelines [27].

Since an early detection of psychological problems, whether externalized or internalized, is one of the pre-conditions of later successful prevention and treatment, in this study we investigated if there was a correlation between the amount of screen time and internalized and externalized mental health problems, as well as the relationship between screen time and the difficulties taking into account the amount of time children spent participating in other, developmentally stimulating activities: outdoor activities and physical activities.

Studies have shown that outdoor activities have a positive impact on attention and 
concentration in children [28]; children who spend more time engaged in outdoor activities are better prepared for school [29], they are less frequently overweight or obese [30] and generally present with better cognitive functioning [31]. Similar results were obtained regarding physical activity of children; physical activity was related to better cognitive functioning [32], lower body weight [33] and better motor skills in children [34]. Here we need to take into account age and sex differences in outdoor and physical activities; between the third and the fifth year of age children, on the average spend $10 \%$ less time engaged in physical activities with every subsequent year [35] while girls, on the average, spend less time outdoor [36] and engaged in physical activities [37] than do boys.

\section{Aim}

The aim of the project Utilising modern technologies in early childhood was to research the use of screens by pre-school children in relation to their development in Croatia at the national level.

The aim of the research Utilising modern technologies and some indicators of mental health in pre-school children in Croatia conducted on the kindergarten children in Croatia was to examine the correlation between the total screen time of children and some indicators of their mental health - emotional reactivity, anxiety/depression, somatic problems, withdrawal, sleeping problems, attention problems, aggressivity and other problems.

In order to obtain the predictors of the total screen time of children, we also examined the moderating effects related to the engagement of children in other content during the workweek: physical activity, playing with peers, total outdoor activity and other activi- ties. We expect statistically significant differences in these categories, in line with theoretical knowledge, but the interpretation is difficult due to insufficient number of studies in this area.

Problems researched were as follows:

1. Examine the correlation of the amount of screen time of children and various internalized/ externalized behaviours.

2. Does the relation between screen time and children's behaviour depend on the amount of time spent in other developmentally stimulating activities?

\section{Participants and methods}

\section{Participants}

This study is a part of the scientific project conducted by the Children and Youth Protection Centre of the City of Zagreb, under the leadership of Professor Gordana Buljan Flander. It has been the first study about the use of modern technologies in early childhood conducted at the national level in Croatia. Data were collected during 2016 and 2017 on the convenience sample of 655 children 18 months to 7 years of age $(\mathrm{M}=5 ; \mathrm{SD}=1.2)$, who attended kindergartens in various rural and urban environments in the Republic of Croatia.

The sample consisted of approximately the same proportion of boys (53\%) and girls $(47 \%)$. Questionnaires were filled in by their carers - $80 \%$ of them were mothers, $19 \%$ fathers, and $1 \%$ of other close persons (grandmother, foster mother). Average age of carers was $36.6(\mathrm{SD}=5.3 ; \min =22 ; \max =59)$. More than $90 \%$ of children lived with both parents, around one third were single children in the family, while others had 1 to 4 siblings, $40 \%$ of these sharing the room with sibling/s. 


\section{Methods}

In collaboration with the management of the kindergarten the child had been attending, meetings with parents were organised in collaboration with the kindergarten management. Parents (carers) filled in the questionnaires described below in controlled conditions, under the guidance of educated examiners - assistants in the research. Data of 655 participants were used in the final analysis.

A special questionnaire was developed for the purpose of this research in order to collect demographic data and data on children's and parents' habits regarding the electronic media. The questionnaire was based on research needs and previous scientific knowledge available in literature.

To assess potential variations in children's behaviour Child behaviour checklist or CBCL) [38] was used. It was filled in by parents who estimated the presence or absence of described behaviour in their child. CBCL 1 1/2-5 (for children from one and a half to five years of age), used in this research, consists of 100 statements describing various behavioural, social and emotional symptoms in children. These symptoms can be broadly classified as internalized or externalized problems. The factor analysis of this broad band scale showed subscales of emotional reactivity, anxiety/depression, somatic problems, withdrawal and sleeping problems on the internalizing dimension, while attention problems and aggressive behaviour were found on the externalizing dimension. The scale being translated to many languages, the seven-factor structure was confirmed for most examined cultures, while the six-factor structure, with emotional reactivity and anxiety/depression combined in one syndrome, was fitting to a small number of cultures. Despite that, there are differences in the intensity of symptoms in different cultures and it is necessary to define national norms prior to utilising this instrument for clinical or research purposes [39]. E.g. Danish preschool children show significantly lower scores than their American peers [40]. Similar results were obtained by Živčić-Bečirević, Smojver-Ažić and Mišćenić [41] who conducted research on the sample of 232 children aged 4 to 7 attending kindergarten Opatija. They found a lower presence of the problems in the total result and on the subscale of emotional reactivity, with similar tendencies on the externalizing dimension and the subscale of aggressive behaviour in Croatian population than it was found in the American population.

In this research, standardisation on Croatian sample was not conducted because a knowledge of norms was not necessary since the focus of research was on the relationship of subscales with other measurements.

Child behaviour checklist or CBCL [38] was first applied on the population of preschool children at the national level in Croatia in the research project Utilising modern technologies in early childhood, which also includes this research.

\section{Results}

In order to examine the correlation between screen time and some developmental outcomes, we analysed the moderating effects of other activities of children in the workweek (physical activity, playing with peers, outdoor activity) and the total time children spent with their parents.

Only the constructs showing statistically significant correlation with screen time were included in the analysis: anxiety-depression, 
shyness and internalization (emotional reactivity), while somatic problems and sleeping problems on the internalizing dimension, as well as attention problems and aggressive behaviour on the externalizing dimension did not show statistically significant correlation with screen time. That was the reason why moderating effects were not tested on these.

Moderating effects were calculated by including the predictor (screen time) in the hierarchical regression analysis in the first step, the second step was adding the potential moderator (other activities) and the third was adding the product of the predictor and the moderator to the two variables, thus showing the interaction effect of the two variables.

If there is a significant increase of the explained variance $\left(\Delta \mathrm{R}^{2)}\right.$ in the third step and if the beta coefficient of the predictor and the moderator product is significant, we can con- sider it a significant moderator effect. The direction of moderation was followed on continuous variables (predictor and moderator) divided in two groups (results above and below the median) and then their interaction on the dependent variable was observed (see Figure 1).

Other children's activities did not present as statistically significant moderators for the scales Withdrawal and Internalization, while only outdoor activity presented as statistically significant on the Anxiety-depression scale. Furthermore, the time parents spent with their children did not present as significant moderator in the correlation between developmental outcomes and screen time, and the time spent playing with peers showed similar effects.

Results in Table 1 also show that the outdoor activity presented as a significant mod-

Table 1. Moderating effect of the child's outdoor activity on the correlation between screen time and anxiety - depression

\begin{tabular}{|c|c|c|c|c|c|c|c|c|c|}
\hline & Predictor & Beta & $\mathrm{t}$ & $\mathrm{p}$ & $\mathrm{R}^{2}$ & $\mathrm{R}_{\text {kor }}^{2}$ & $\mathrm{~F}\left(\mathrm{R}^{2}\right)$ & $\Delta \mathrm{R}^{2}$ & $\mathrm{p}\left(\Delta \mathrm{R}^{2}\right)$ \\
\hline 1 & $\begin{array}{l}\text { screen time workday, } \\
\text { total }\end{array}$ & 0.153 & 3.850 & 0.000 & 0.023 & 0.022 & $14.822^{* *}$ & & \\
\hline \multirow[t]{2}{*}{2} & $\begin{array}{l}\text { screen time workday, } \\
\text { total }\end{array}$ & 0.146 & 3.657 & 0.000 & \multirow{2}{*}{0.025} & \multirow{2}{*}{0.022} & \multirow{2}{*}{$8.026 * *$} & \multirow{2}{*}{0.002} & \multirow{2}{*}{0.269} \\
\hline & $\begin{array}{l}\text { child's outdoor activity } \\
\text { workday }\end{array}$ & 0.044 & 1.106 & 0.269 & & & & & \\
\hline \multirow[t]{3}{*}{3} & $\begin{array}{l}\text { screen time workday, } \\
\text { total }\end{array}$ & -0.006 & -0.081 & 0.936 & \multirow{3}{*}{0.034} & \multirow{3}{*}{0.030} & \multirow{3}{*}{$7.369 * *$} & \multirow{3}{*}{$0.009 *$} & \multirow{3}{*}{0.015} \\
\hline & $\begin{array}{l}\text { child's outdoor activity } \\
\text { workday }\end{array}$ & -0.106 & -1.440 & 0.150 & & & & & \\
\hline & Mod4_ST.otv. & 0.248 & 2.435 & 0.015 & & & & & \\
\hline
\end{tabular}

* significant at the level of $5 \%(p<0.05)$; ** significant at the level of $1 \%(p<0.01)$

Beta - beta coefficient; $\mathrm{t}$ - $\mathrm{t}$ value; $\mathrm{p}$ - significance; $\mathrm{R}^{2}$ - R-squared; $\mathrm{R}^{2} \mathrm{kor}$ - corrected multiple determination coefficient; $F\left(R^{2}\right)$ - f-test R-squared; $\Delta R^{2}$ - R-squared change; $p\left(\Delta R^{2}\right)$ - significance of $\mathrm{R}$-squared change 


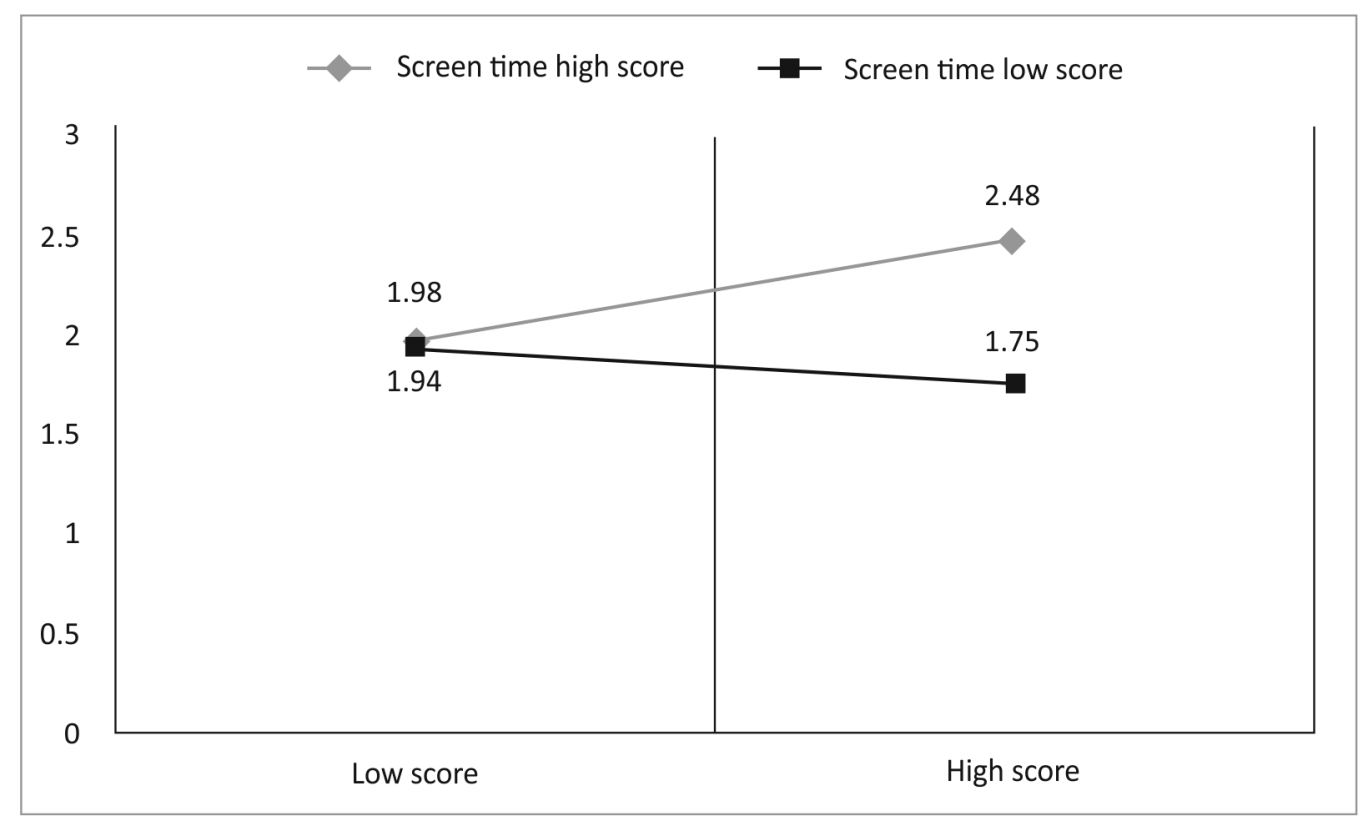

Figure 1. Direction of the moderating effect of outdoor activity on the correlation between screen time and anxiety-depression

erator of the correlation between screen time and anxiety-depression in children. The direction of that moderation is seen on Figure 1.

According to Figure 1, we can see that children with highest levels of anxiety-depression are those who spend more screen time, but also spend more time in outdoor activities, while children with lowest levels of anxiety-depression spend much time outdoor and little screen time.

\section{Shyness}

While previous results are related to children of all age groups, there is a moderation effect on the correlation between physical activity and screen time relating to Withdraw- al, but only in children younger than 6 (preschool children).

As shown in Table 3, there is a significant increase of the explained variance of withdrawal in the third step, and the regression coefficient of the interaction of physical activity and screen time is statistically significant (beta $=-.270$, p.05). The direction of moderation is shown on Figure 2.

Figure 2 shows that children with high number of screen time hours and low physical activity present with highest levels of withdrawal. However, withdrawal subsides, which is not the case in children who spend little screen time. Physical activity has protective ability in cases of increased exposure to screen time, i.e. it reduces the levels of withdrawal in such children. 
Table 2. Moderating effect of physical activity on the correlation between screen time and shyness

\begin{tabular}{|c|c|c|c|c|c|c|c|c|c|}
\hline & Predictor & Beta & $\mathrm{t}$ & $\mathrm{p}$ & $\mathrm{R}^{2}$ & $\mathrm{R}_{\text {kor }}^{2}$ & $\mathrm{~F}\left(\mathrm{R}^{2}\right)$ & $\Delta \mathrm{R}^{2}$ & $\mathrm{p}\left(\Delta \mathrm{R}^{2}\right)$ \\
\hline 1 & $\begin{array}{l}\text { screen time workday } \\
\text { total }\end{array}$ & 0.162 & 3.568 & 0.000 & 0.026 & 0.024 & $12.730^{* *}$ & & \\
\hline \multirow[t]{2}{*}{2} & $\begin{array}{l}\text { screen time workday } \\
\text { total }\end{array}$ & 0.162 & 3.569 & 0.000 & \multirow{2}{*}{0.026} & \multirow{2}{*}{0.022} & \multirow{2}{*}{$6.368^{* *}$} & \multirow{2}{*}{0.000} & \multirow{2}{*}{0.860} \\
\hline & $\begin{array}{l}\text { Child's physical activity } \\
\text { workday }\end{array}$ & -0.008 & -0.177 & 0.860 & & & & & \\
\hline \multirow[t]{3}{*}{3} & $\begin{array}{l}\text { screen time workday } \\
\text { total }\end{array}$ & 0.335 & 4.038 & 0.000 & \multirow{3}{*}{0.039} & \multirow{3}{*}{0.033} & \multirow{3}{*}{$6.345^{* *}$} & \multirow{3}{*}{$0.013 *$} & \multirow{3}{*}{0.013} \\
\hline & $\begin{array}{l}\text { Child's physical activity } \\
\text { workday }\end{array}$ & 0.160 & 1.964 & 0.050 & & & & & \\
\hline & Mod1_ST.fizak & -0.270 & -2.482 & 0.013 & & & & & \\
\hline
\end{tabular}

* significant at the level of $5 \%(p<0.05)$; ** significant at the level of $1 \%(p<0.01)$

Beta - beta coefficient; $\mathrm{t}$ - t value; $\mathrm{p}$ - significance; R2 - R-squared; R2kor - corrected multiple determination coefficient; $\mathrm{F}(\mathrm{R} 2)$ - f-test R-squared; $\Delta \mathrm{R} 2$ - R-squared change; $\mathrm{p}(\Delta \mathrm{R} 2)$ - significance of R-squared change

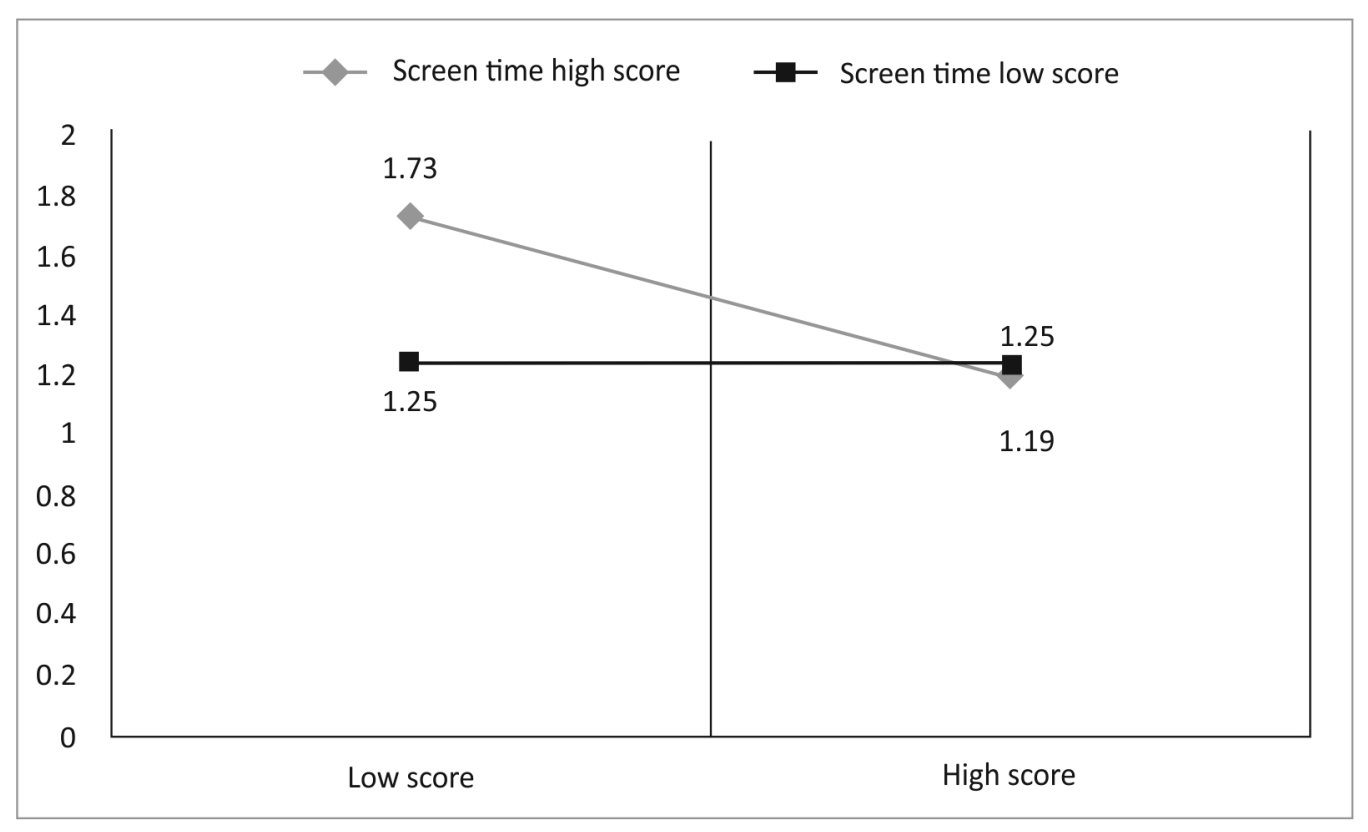

Figure 2. Direction of the moderating effect of physical activity on the correlation between screen time and shyness 


\section{Discussion}

In this research we found that when children spend little time in outdoor activities, they show equal level of anxiety and depression symptoms, while increased time in outdoor activities has positive effects on children with low screen time (there is a reduction in anxiety/depression symptoms), and negative effects on children with high screen time (anxiety/depression symptoms increase). Studies showing that outdoor activities have a positive effect on children [42], the question arises why there is still an increase of anxiety/ depression symptoms in children with high screen time.

Reviewing studies dealing with the correlation between parental characteristics and the time spent in outdoor activities of children aged 0 to 12, Boxberg and Reimes [43] found that more time spent in outdoor activities correlates with some parental characteristics, like mother's employment and lower socio-economic status of parents; parents of high socio-economic status more often engage their children in organised and structured activities and spend more time in family activities. Furthermore, low socio-economic status, low parents' education and financial worries are related to higher parental stress, lower child well-being and higher level of anxiety and depression in children $[44,45]$. Therefore, it is possible that less screen time has the effect of a protective factor from unfavourable parents' characteristics which more often occur in children who spend much time in outdoor activities. Children who spend less screen time, also spend more time in family activities, have more stimulating home environment and higher level of parental engagement [46]. There is less chance that such children's high level of outdoor activity is the result of their parents' inability to spend more quality time with them or engage them in some structured activities, but of parents' belief in the importance of outdoor activities for their children's healthy development [43].

In this research we also found that among the children who have a low level of physical activity, those who spend much screen time are more withdrawn than those who spend little screen time. The increase of physical activity is linked with the decrease of withdrawal in children with high screen time, while in those with low screen time, it is insignificant. In this case we can say that physical activity is a protective factor for children who spend much screen time.

Various studies confirm that more screen time is linked to weaker social skills in children [47]. Considering the elements on the dimension of withdrawal in Achenbach's Child behaviour checklist (CBCL) (e.g. Refuses to actively participate in the game; Avoids eye-contact; Withdrawn, Does not participate in activities with others) we may conclude that there is probably a significant overlap of this dimension and social anxiety and similar constructs. Although there are no studies into the link of specific subscale withdrawal and social anxiety, research by Kopala-Sibley and Klein [48] showed that withdrawal and a lack of social interest are associated with higher total score on subscales of affective and anxiety problems (including the withdrawal subscale) on CBCL in later life.

In this research, playing in the park, running, jumping and sport were given as examples of physical activity in the Questionnaire on using modern technologies by pre-school children. Studies show that physical and sport activity have positive effects on pre-school children's development [49], while participation in team sports reduces social anxiety over time [50]. Children engaged in sport ac- 
tivities were found to be less shy and withdrawn than children who were not engaged in such activities [51].

These studies support the hypothesis that physical activity is a protective factor for withdrawn children and those who spend much screen time. Although causal connections between withdrawal and a high level of screen time is not known it is apparent that physical activity reduces that negative influence (it is also possible that withdrawn children choose stand-alone activities like screen time, and that the children who spend much screen time spend less time playing or activities with other children, thus missing opportuni-

\section{References}

1. Brown A, Smolenaers E. Parents' interpretations of screen time recommendations for children younger than 2 years. J Fam Issues. 2018;39:406-29.

2. Charach A, Bélanger SA, McLennan JD, Nixon MK. Screen time and young children: Promoting health and development in a digital world. Paediatr Child Health. 2017;461:468.

3. Currie C, Zanotti C, Morgan A, Currie D, de Looze M, Roberts C, et al. Social determinants of health and well-being among young people. Health Behaviour in School-aged Children (HBSC) study: international report from the 2009/2010 survey. Denmark: WHO Regional Office for Europe, 2012. p.252.

4. Briggs-Gowan MJ, Carter AS, Skuban EM, Horwitz SM. Prevalence of social-emotional and behavioral problems in a community sample of 1-and 2-year-old children. J Am Acad Child Adolesc Psychiatry. 2001;40:811-9.

5. Klein Velderman M, Crone M, Wiefferink $\mathrm{CH}$, Reijneveld SA. Identification and management of psychosocial problems among toddlers by preventive child health care professionals. Eur J Public Health. 2009;20:332-8. ties to develop social skills which would help them to better get along and fit in with other children). Consequently, children who spend much screen time are not more withdrawn than children who spend little screen time if the former are engaged in high levels of physical activity.

\section{Acknowledgements}

None.

\section{Conflict of Interest}

The authors report no conflict of interest.
6. Weitzman C, Edmonds D, Davagnino J, BriggsGowan MJ. Young child socioemotional/behavioral problems and cumulative psychosocial risk. Infant Ment Health J. 2014;35:1-9.

7. McDonald SW, Kehler HL, Tough SC. Risk factors for delayed social-emotional development and behavior problems at age two: Results from the All Our Babies/Families (AOB/F) cohort. Health Sci Rep. 2018;1:e82.

8. Bayer JK, Hiscock H, Ukoumunne OC, Price A, Wake M. Early childhood aetiology of mental health problems: a longitudinal population-based study. J Child Psychol Psychiatry. 2008;49:1166-74.

9. Caspi A. The child is father of the man: personality continuities from childhood to adulthood. J Pers Soc Psychol. 2000;78:158-72.

10. Caspi A, Harrington H, Milne B, Amell JW, Theodore RF, Moffitt TE. Children's behavioural styles at age 3 are linked to their adult personality traits at age 26. J Pers. 2003;71:495-514.

11. Fergusson D, Boden J, Hayne H. Childhood conduct problems. In: Gluckman P, Hayne H, eds. Improving the Transition: Reducing Social and Psychological Morbidity During Adolescence. New Zealand: Office of the Prime Minister's Science Advisory Committee; 2011. p. 59-78. 
12. Patterson GR, DeBaryshe BD, Ramsey E. A developmental perspective on antisocial behavior. Am Psychol. 1989;44:329-35.

13. LeBlanc AG, Katzmarzyk PT, Barreira TV, Broyles ST, Chaput JP, Church TS, et al. Correlates of total sedentary time and screen time in 9-11 year-old children around the world: the international study of childhood obesity, lifestyle and the environment. PloS one. 2015;10:e0129622.

14. Lee SC, Koleilat M, Hernandez LM, Whaley SE, Davis JN. Screen time associated to unhealthy diets in low-income children. J. Food Nutr Res. 2016;4:94-99.

15. Potter M, Spence JC, Boulé NG, Stearns JA, Carson V. Associations between physical activity, screen time, and fitness among 6-to 10-year-old children living in Edmonton, Canada. Appl Physiol Nutr Metab. 2017;42:487-94.

16. Tanaka C, Tanaka M, Okuda M, Inoue S, Aoyama T, Tanaka S. Association between objectively evaluated physical activity and sedentary behavior and screen time in primary school children. BMC Res Notes. 2017;10:175.

17. Porter RM, Tindall A, Gaffka BJ, Kirk S, Santos M, Abraham-Pratt I, et al. A review of modifiable risk factors for severe obesity in children ages 5 and under. Child Obes. 2018;14:468-76.

18. Webster EK, Martin CK, Staiano AE. Fundamental motor skills, screen-time, and physical activity in preschoolers. J Sport Health Sci. 2018;8:11421.

19. Marinelli M, Sunyer J, Alvarez-Pedrerol M, Iñiguez C, Torrent, M, Viogue J, et.al. Hours of television viewing and sleep duration in children: $\mathrm{A}$ multicenter birth cohort study. JAMA Pediatr. 2014;168:458-64.

20. Manganello JA, Taylor CA. Television exposure as a risk factor for aggressive behavior among 3-year-old children. Arch Pediatr Adolesc Med. 2009;163:1037-45.

21. Ferguson CJ. The influence of television and video game use on attention and school problems: A multivariate analysis with other risk factors controlled. J Psychiatr Res. 2011;45:808-13.

22. Gentile DA, Swing EL, Lim CG, Khoo A. Video game playing, attention problems, and impulsiveness: evidence of bidirectional causality. Psychol Pop Media Cult. 2012;1:62-70.
23. Verlinden M, Tiemeier H, Veenstra R, Mieloo C, Jansen W, Jaddoe VWV, et al. Television viewing through ages 2-5 years and bullying involvement in early elementary school. BMC Public Health. 2014;14:157.

24. Chonchaiya W, Sirachairat C, Vijakkhana N, Wilaisakditipakorn T, Pruksananonda C. Elevated background TV exposure over time increases behavioural scores of 18-month-old toddlers. Acta Paediatr. 2015;104:1039-46.

25. American Academy of Pediatrics. Media and young minds. Pediatrics. 2016;138:e20162591.

26. Roje M, Flander GB, Tarabić BN. Young children in front of little screens. In: Cubela Adorić V, Franc R, Kalebić Maglica B, Nakić Radoš S, eds. Psihologija u promociji i zaštiti ljudskih prava i društvene pravednosti. Zadar: Hrvatsko psihološko društvo; 2017. p. 162.

27. Christakis AD. The effects of infant media usage: what do we know and what should we learn? Acta Paediatr. 2009;98:8-16.

28. Ulset V, Vitaro F, Brendgen M, Bekkhus M, Borge AIH. Time spent outdoors during preschool: links with children's cognitive and behavioral development. J Environ Psychol. 2017;52:69-80.

29. Becker DR, Grist CL, Caudle LA, Watson MK. Complex Physical Activities, Outdoor Play, and School Readiness among Preschoolers. Global Education Review. 2018;5:110-22.

30. Kimbro RT, Brooks-Gunn J, McLanahan S. Young children in urban areas: links among neighborhood characteristics, weight status, outdoor play, and television watching. Soc Sci Med. 2011;72:668-76.

31. Wells NM. At home with nature: Effects of "greenness" on children's cognitive functioning. Environ Behav. 2000;32:775-95.

32. Sánchez López M, Cavero Redondo I, Alvarez Bueno C, Ruiz Hermosa A, Pozuelo Carrascosa DP, Díez Fernández A, et al. Impact of a multicomponent physical activity intervention on $\operatorname{cog}$ nitive performance: the MOVI KIDS Study. Scand J Med Sci Sports. 2019;29:766-775.

33. Prentice-Dunn H, Prentice-Dunn S. Physical activity, sedentary behavior, and childhood obesity: a review of cross-sectional studies. Psychol Health Med. 2012;17:255-73.

34. Robinson LE. The relationship between perceived physical competence and fundamental motor skills 
in preschool children. Child Care Health Dev. 2011;37:589-96.

35. Hinkley T, Salmon J, Okely AD, Hesketh K, Crawford D. Correlates of preschool children's physical activity. Am J Prev Med. 2012;43:159-67.

36. Klinker CD, Schipperijn J, Kerr J, Ersbøll AK, Troelsen J. Context-specific outdoor time and physical activity among school-children across gender and age: using accelerometers and GPS to advance methods. Front Public Health. 2014;2:20.

37. Schmutz EA, Leeger-Aschmann CS, Radtke T, Muff S, Kakebeeke TH, Zysset AE, et al. Correlates of preschool children objectively measured physical activity and sedentary behavior: a crosssectional analysis of the SPLASHY study. Int J Behav Nutr Phys Act. 2017;14:1.

38. Achenbach TM. Achenbach system of empirically based assessment (ASEBA). Encyclopedia of Clinical Neuropsychology. 2017:1-7.

39. Ivanova MY, Achenbach TM, Rescorla LA, Harder VS, Ang RP, Bilenberg N, et al. Preschool psychopathology reported by parents in 23 societies: testing the seven-syndrome model of the child behavior checklist for ages 1.5-5. J Am Acad Child Adolesc Psychiatry. 2010;49:1215-24.

40. Kristensen S, Henriksen TB, Bilenberg N. The Child Behavior Checklist for Ages 1.5-5 (CBCL/1 $\left.1 \frac{1}{2}-5\right)$ : Assessment and analysis of parent-and caregiverreported problems in a population-based sample of Danish preschool children. Nord J Psychiatry. 2010;64:203-9.

41. Živčić-Bečirević, I., Smojver-Ažić, S., Mišćenić, G. Problemi u ponašanju predškolske djece prema procjeni roditelja i odgojitelja. Psihologijske teme. 2003;12:63-76.

42. Monti F, Farné R, Crudeli F, Agostini F, Minelli $\mathrm{M}$, Ceciliani A. The role of outdoor education in child development in Italian nursery schools. Early Child Dev Care. 2019;189:867-82.
43. Boxberger K, Reimers AK. Parental Correlates of Outdoor Play in Boys and Girls Aged 0 to $12-\mathrm{A}$ Systematic Review. Int J Environ Res Public Health. 2019;16:190.

44. McConnell D, Breitkreuz R, Savage A. From financial hardship to child difficulties: Main and moderating effects of perceived social support. Child Care Health Dev. 2011;37:679-91.

45. Merz EC, Tottenham N, Noble KG. Socioeconomic status, amygdala volume, and internalizing symptoms in children and adolescents. J Clin Child Adolesc Psychol. 2018;47:312-23.

46. Duch H, Fisher EM, Ensari I, Harrington A. Screen time use in children under 3 years old: a systematic review of correlates. Int J Behav Nutr Phys Act. 2013;10:102.

47. Carson V, Lee EY, Hesketh KD, Hunter S, Kuzik N, Predy M, et al. Physical activity and sedentary behavior across three time-points and associations with social skills in early childhood. BMC public health. 2019;19:27.

48. Kopala-Sibley DC, Klein DN. Distinguishing types of social withdrawal in children: Internalizing and externalizing outcomes of conflicted shyness versus social disinterest across childhood. J Res Pers. 2017;67:27-35.

49. McNeill J, Howard SJ, Vella SA, Santos R, Cliff DP. Physical activity and modified organized sport among preschool children: Associations with cognitive and psychosocial health. Ment Health Phys Act. 2018;15:45-52.

50. Schumacher Dimech A, Seiler R. Extracurricular sport participation: A potential buffer against social anxiety symptoms in primary school children. Psychol Sport Exerc. 2011;12:347-54.

51. McHale JP, Vinden PG, Bush L, Richer D, Shaw D, Smith B. Patterns of personal and social adjustment among sport-involved and noninvolved urban middle-school children. Sociol Sport J. 2005;22:119-36. 


\section{Korištenje suvremenih tehnologija i nekih pokazatelja mentalnog zdravlja predškolske djece u Hrvatskoj}

Sažetak- lako je tijekom proteklog desetljeća proveden niz studija o povezanosti vremena provedenim pred zaslonom s ishodom razvoja djece, većina studija uglavnom se bavi problemom pretilosti i tjelesne sposobnosti djece, dok su tek rijetke studije ispitivale povezanost vremena provedenog uz zaslone i mentalnog zdravlja, a posebno nedostaje istraživanja koja se tiču internaliziranih problema djece. Rano otkrivanje psiholoških problema jedan je od temelja uspješne prevencije i liječenja, a neka istraživanja pokazuju da čak $20 \%$ djece, uključujući i djecu vrtićke dobi, pokazuje određene psihološke poteškoće, te da su određena ponašanja predškolske djece povezana s raznim mentalnim poremećajima i problemima u odrasloj dobi. Cilj ovog istraživanja bio je ispitati korelaciju između ukupnog vremena provedenog uz zaslone i nekih pokazatelja mentalnog zdravlja djece - emocionalne reaktivnosti, anksioznosti / depresije, somatskih problema, povlačenja, problema sa spavanjem, problema s pažnjom i drugih problema, u uzorku Hrvatske djeca koja pohađaju vrtiće. Također smo ispitali moderirajuće učinke uključenosti djeteta u druge aktivnosti, kao što su tjelesna aktivnost, igranje s vršnjacima, ukupne aktivnosti na otvorenom i vrijeme provedeno u drugim aktivnostima. $U$ ovom su radu istraženi potencijalni rizični i zaštitni čimbenici povezani sa vremenom provedenim uz zaslone u djece predškolske dobi s naglaskom na njihovo mentalno zdravlje.

Ključne riječi: predškolska djeca, ekrani, slobodno vrijeme, mentalno zdravlje 